\title{
IMMigRation In THE POSTCOLONIAL ERA: MIMICRY AND Ambivalence in Chimamanda Ngozi Adichie's the ARrangers OF MARRIAGE
}

\author{
Alireza Sardari \\ Payame Noor University \\ alireza.sardari@ymail.com
}

\begin{abstract}
It is well established that immigration brings about fundamental changes and the immigrant faces significant challenges in the new culture. This research uses Homi Bhabha's critical theories of mimicry and ambivalence to determine the effects of 'state of mimicry', and to pinpoint the 'site of identity' in the immigration experience in Chimamanda Ngozi Adichie's The Arrangers of Marriage (2009). The results indicate that antagonist's (Ofodile) 'state of mimicry' continuously grows him apart from his wife Chinaza (protagonist) and intensifies gender inequality against her in their relationship. In addition, the results indicate that protagonist's 'site of identity' is fluid and not fixed, and this place-lessness of identity is because of the never-ending comparison between her past with the present situation she experiences as an immigrant.
\end{abstract}

Keywords: African literature, Postcolonial theory, Immigration, Gender inequality

\section{INTRODUCTION}

There are serious questions about immigration, "What can we ask of immigrants once they arrive? Should they be expected to assimilate, or can they properly demand that we make room for the different cultures they bring with them? And so on" (Miller 2016, p. 1). Immigration is of leaving the familiar for the unfamiliar; of giving up what one has to achieve what one desires. It is undeniable that the immigrant leaves behind a part of his identity in his homeland and feels its absence at the new home. And when he returns to his homeland, he again leaves behind another part of his identity. Immigration is where the absence of something is always present as the immigrant lives 'in-between' his past and present. Immigration is the crossroad of fear and hope where the immigrant can neither forget his past nor look at the future with certainty. Perhaps the greatest lesson of immigration for humanity is that "Living is bathing in the pool of the "now" (Sepehri 2013, para. 56). The immigrant learns to choose 'here and now' between his past that is gone and the ambiguous future that is still to come. Yes. Immigration is the story of 'Now'.

Nigerian-born Chimamanda Ngozi Adichie (b.1977) is one of the leading African literary figures who belong to what is generally known as the third generation of African writers. A generation "born and educated after 1960, who never personally experienced the colonial period, and whose writings began to appear in the mid-1980s. They include Ben Okri, Helen Oyeyemi, Sefi Atta, Chris Abani, Helon Habila, Okey Ndibe, Uzodinma Iweala, and now also Adichie" (Kurtz 2012, p. 24). Adichie's first novel, Purple Hibiscus (2003) received critical acclaim and brought her fame across literary circles. As a prominent writer, she "takes up her pen in order to present a 'true image' of African people and the African past in order to contest racist misrepresentations and erasures" (Eisenberg 2013, p. 9). Her works has been translated into over thirty languages, and she also has received numerous awards and honors including MacArthur Fellowship known as the "Genius Grant" (2008), and honorary doctorate degrees from the University of Edinburgh, Duke University, Yale University, and etc. "All this has placed Adichie prominently among a group of young Nigerian writers whose efforts are revitalizing West African writing" (Kurtz 2012, p. 24). Adichie's works focus on different concerns such as identity, race, gender inequality, and otherness that are in line with postcolonial issues.

The Arrangers of Marriage is a short story in the collection The Thing Around Your Neck (2009). It is about a Nigerian girl named Chinaza who lives in Lagos with her Aunty Ada and uncle Ike. They have found Chinaza a new husband named Ofodile who is "a doctor in America" (Adichie 2009, para. 11). They get married in Lagos and move to New York. Ofodile, fully absorbed in American culture, has changed his name to Dave Bell. From day one, he starts correcting Chinaza's speaking and reminds her to act like a local, not a foreigner. He even changes Chinaza's name to Agatha Bell for her green card application. Chinaza is shocked when Ofodile tells her about his prior marriage. She feels disrespected 
by Ofodile's behavior and befriends their downstairs neighbor named Nia who seems to be supportive. Chinaza feels frustrated and decides to start a new life for herself in America.

The present research applies Homi Bhabha's theories of mimicry and ambivalence reflected in his seminal work The Location of Culture (1994) to investigate the cultural issues in The Arrangers of Marriage (2009). Therefore, this study answers the following questions: First, In the postcolonial era, what is the effect of 'state of mimicry' in the immigration experience? Second, where is the 'site of identity' in the immigration experience?

\section{MATERIALS AND METHOD}

\section{II.1 Mimicry}

Mimicry, an important concept in postcolonial studies, describes "the ambivalent relationship between colonizer and colonized" (Ashcroft, et al., 2013, p. 154). Mimicry discloses the colonial goal of 'making the colonized to be like the colonizer', and crystalizes the postcolonial situation that is nothing but to-the-end-of-time conflict between colonizer and colonized; between those who recklessly struggle to fulfill their boundless desires versus those who speak out against the colonial rationale. Authority is the keyword in this cultural process. Imposing the colonial rule over the colonized, the colonial hegemony soon or late will be disappeared because when the colonized imitates _or is encouraged to imitate the colonizer, the boundary between the two starts to blur. In result, difference gives its place to similarity. In this process of cultural struggle, colonial authority is constantly challenged: Fighting the colonized, the colonizer is, in fact, denying his own colonial authority because colonized has become roughly identical with the colonizer. Mimicry empowers the colonized to elude the self-defeating authority of the colonizer. In this regard, Gandhi (2019) says,

mimicry is also the sly weapon of anti-colonial civility, an ambivalent mixture of deference and disobedience. The native subject often appears to observe the political and semantic imperatives of colonial discourse. But at the same time, she systematically misrepresents the foundational assumptions of this discourse by articulating it. . . . In other words, 'mimicry' inaugurates the process of anti-colonial self-differentiation through the logic of inappropriate appropriation. (pp. 149-150)

Mimicry is an ambivalent site in which both colonizer and colonized give and take qualities from each other. As the colonized is encouraged to adapt to the dominant culture, both sides become almost the same. This cultural process opens a space for the colonized to mimic the colonizer exaggeratedly. The result is not 'a simple reproduction of those traits. Rather, the result is a 'blurred copy' of the colonizer that can be quite threatening. This is because mimicry is never very far from mockery, since it can appear to parody whatever it mimics. Mimicry therefore locates a crack in the certainty of colonial dominance, an uncertainty in its control of the . . colonized" (Ashcroft, et al., 2013, p. 155). In other words, when the colonized is encouraged to imitate the colonizer, the difference between them diminishes gradually. As a result, the colonial superiority is challenged. Ergo, the colonized has the power to affect the dominant culture and ultimately resist the colonial discourse. Bhabha (1994) states, "colonial mimicry is the desire for a reformed, recognizable Other, as a subject of a difference that is almost the same, but not quite. Which is to say, that the discourse of mimicry is constructed around an ambivalence; in order to be effective, mimicry must continually produce its slippage, its excess, its difference" (p. 86). This uncertain situation makes the colonizer anxious since he realizes when both sides are alike, then, the colonial power does not have exclusive authority over the colonized anymore. "Mimicry is ambivalent because it requires a similarity and a dissimilarity. It relies on resemblance, on the colonized becoming like the colonizer but always remaining different. . . . With mimicry the authoritative discourse becomes displaced as the colonizer sees traces of himself in the colonized: as sameness slides into otherness" (Childs \& Williams 1997, pp. 129-130). Mimicry, as Huddart (2006) states, "examines the ways that the colonized retain their power to act despite the apparent domination of the colonizer" (p. 6). What is undeniable is that mimicry overturns the seat of power and finally discredits the colonizer's cultural superiority. Huddart (2006), elsewhere asserts, "a further consequence of mimicry is the undermining of the colonizer's apparently stable, original identity. . . . The identity of the colonizer is constantly slipping away, being undermined by effects of writing, joking, 'sly civility', and repetition" (p. 51). 


\section{II.2 Ambivalence}

Ambivalence is another keyword in Bhabha's thinking that "signifies the condition produced through the discourse of mimicry, whereby ... there is produced, says Bhabha, a difference, slippage or excess. Thus, the colonial other is produced as almost, but not quite, the same, thereby producing disquiet in the colonialist, and thus a renewal of the fear of the other" (Wolfreys, et al., 2006, p. 7). Ambivalence, in other words, spotlights the fact that culture is not a one-way path where only one participant affects others. Culture is a circle where every participant has the potential to affect others. That is why culture is already an ambivalent condition, a land belonging to no one. Consequently, the theory of ambivalence exposes the inherent contradictions in the colonial discourse where the authenticity of the colonizer is questioned. Bhabha believes, "object of colonial discourse is marked by ambivalence because it is derided and also desired, like the colonial fantasy to be in 'two places at once', to be colonizer and colonized. Ambivalence thus involves a process of identification and of disavowal" (Childs \& Williams 1997, p. 124).

\section{RESULTS AND DISCUSSION}

\section{III.1 Mimicry in the Immigration Experience}

In The Arrangers of Marriage, Ofodile is a true incarnation of imitation since he abandons his own name, language and identity to feel included in the American society. For example, when Chinaza calls her family in Nigeria, Ofodile asks "“'Did you get through?'. . . . 'It's engaged,' I said. 'Busy. Americans say busy, not engaged,' he said" (Adichie 2009, para. 13). He is desperate to assimilate into the American culture as he only uses English (and not Igbo language) with Chinaza at home. "'You have to speak English at home, too, baby. So you can get used to it"' (para. 41). Ofodile's cultural alienation from his roots is to the extent that he rejects any sign linking him to his Nigerian identity. Ofodile's behavior reveals his will to subjugate Chinaza when he buys an American cookbook for her and justifies his action by saying "I don't want us to be known as the people who fill the building with smells of foreign food" (Adichie 2009, para. 43). Ofodile's will to power in companionship with Chinaza's lack of power indicates their exact opposite situations at the same home, at the same time. For Chinaza, to cook familiar food evokes a sense of homeland, a sense of belonging, a sense of home. McLeod (2010) elaborates on the concept of 'home',

a valuable means of orientation by giving us a fixed, reliable sense of our place in the world. It is meant to tell us where we originated from and apparently where we legitimately belong. As an idea it stands for shelter, stability, security and comfort (although actual experiences of home may well fail to deliver these promises). To be 'at home' is to occupy a location where we are welcome, where we can be with people we may regard very much like ourselves, where we are not at sea but have found safe harbor. (p. 142)

It is true. Home is where we are ourselves with no need to hide our identities. Home is the safe harbor where inclusion overpowers exclusion. On the contrary, Ofodile's cultural alienation prompts him to pretend he is unfamiliar with his Nigerian roots. All he desires is to feel included in the American society at all costs. Thus, Culinary tradition, as a point of commonality between them, acts as a point of divergence where they have grown distant from each other. Ofodile's cultural alienation is a cul-de-sac, beginning with egotism and ending with relationships falling apart. That is, he uses others to achieve his desires. The circle of Ofodile's selfish thinking even extends to his relationship with Chinaza, humiliating her for being herself and forcing her to behave following his instructions. Needless to say, his self-centered worldview harms his relationships. And, of course, the results of these relationships are unpleasant. For example, when Chinaza says, "I thought I would have my work permit by now" (Adichie 2009, para. 52). Ofodile responds, "The American woman I married to get a green card is making trouble,'... ' Our divorce was almost final, but not completely, before I married you in Nigeria. Just a minor thing, but she found out about it and now she's threatening to report me to Immigration. She wants more money"' (para. 54). Chinaza is shocked hearing what she hears. She asks Ofodile, "'You were married before?"” (Adichie 2009, para. 55). Ofodile answers, "'It was just on paper. A lot of our people do that here. It's business, you pay the woman and both of you do paperwork together but sometimes it goes wrong and either she refuses to divorce you or she decides to blackmail you'" (para. 55). Regarding Ofodile's behaviour, it should be mentioned that egotism and boundless desires are two sides of the same coin. When Chinaza asks, “'Why did you marry me?"” (Adichie 2009, para. 57). 
Ofodile answers, “'I was happy when I saw your picture,'. . . 'You were light-skinned. I had to think about my children's looks. Light-skinned blacks fare better in America" (para. 59). This selfexplanatory conversation reveals Ofodile's worldview. For him, Chinaza is only a tool of satisfaction and nothing more. Everyone should be there for Ofodile and nothing more. This conversation is a perfect reflection of his thoughts that is nothing but manipulating others for his own benefit. In his relationships, Ofodile thinks only of himself and considers his wife and others only as a means to achieve his goals even at the cost of upsetting them. There is no sense of equality, commitment, or even respect, and this is the beginning of the end of morality in human relationships.

One of the consequences of displacement is the struggle to fit in the new environment. Ofodile is desperate to be accepted in America. His attitude is contrary to what Chinua Achebe, in The Novelist as Teacher, wishes for his society, to "regain belief in itself and put away the complexes of the years of denigration and self-abasement" (Achebe 1976, pp. 58-9). Ofodile and Chinaza are from the same society, but they have different worldviews; two sides of a binary of which Chinaza cherishes her roots while Ofodile is ashamed of his origin. And mimicry nestles in the crossroads of self-humiliation for one's origin and desperation to fit in with the new culture.

\section{III.2 Ambivalence in the Immigration Experience}

The Arrangers of Marriage is more than anything else the narrative of assumption versus reality. At the beginning of the story, Chinaza's words expose her frustration after arriving at Ofodile's apartment with "musty smells hung heavy in the air" (Adichie 2009, para. 3). The way Chinaza narrates her first encounter with the new home is nothing but mixed feelings of an immigrant with very high expectations. "When he told me about our home. I had imagined a smooth driveway snaking between cucumber-colored lawns, a door leading into a hallway, walls with sedate paintings. A house like those of the white newlyweds in the American films that NTA showed on Saturday nights" (para. 2). Facing unwelcoming atmosphere such as "both rooms lacked a sense of space, as though the walls had become uncomfortable with each other, with so little between them" (Adichie 2009, para. 4). And "airless hallway with frayed carpeting" (para. 1) make Chinaza disappointed. In the case of human immigration, understanding (looking at) something from a faraway position is what I call "immigration overestimation'. That is, imagining the immigration as it should be, not as it really is, to flee here and now.

To pinpoint ambivalence in the colonial discourse, we should acknowledge that immigrant's background is as equally important as his present situation. Minh-Ha (2010) comments,

I am a stranger to myself and a stranger now in a strange land. There is no arcane territory to return to. For I am no more an "overseas" person in their land than in my own. Sometimes I see my country people as complete strangers. But their country is my country. In the adopted country, however, I can't go on being an exile or an immigrant either. It's not a tenable place to be. I feel at once more in it and out of it. Out of the named exiled, migrant, hyphenated, split self. The margin of the center. . . . The fragment of Woman. . . . Here too, Their country is My country. (p. 34)

Immigration is a challenging decision since the immigrant experiences feelings that if he had not immigrated, he might never have experienced. Feelings like being 'in-between'. That is, being an insider and outsider simultaneously and feeling alone in a group. The immigrant's attitudes change after immigration because he does not look at the concepts such as home, homeland, friendship, family, loneliness, and nostalgia the same as he did in the past. Lubecka (2012) states that the "identity dilemma implied by immigrant stories often additionally results in making the narrator experience his/her strangeness in a more acute way as they make him/her aware of a gap between the mother culture values $\mathrm{s} / \mathrm{he}$ cherishes but which might be neither understood nor approved of in the new country and the host culture values s/he cannot fully identify with" (p. 139). And this is because culture is gradually institutionalized over time. Thus, culture should not be expected to be immediately forgotten or accepted.

Chinaza criticizes the traditional arrangement of marriages where elders of the family decide who one should marry. For example, when Ofodile snores, Chinaza finds it disturbing and talks to herself, "they did not warn you about things like this when they arranged your marriage" (Adichie 2009, para. 6). This phrase shows her criticism toward traditional marriages. When Aunty Ada told her "'You will have plenty of time to get to know each other before the wedding"" (para. 11). Chinaza said "'Yes, Aunty.' 'Plenty of time' was two weeks" (Adichie 2009, para. 11). Two weeks is not enough time. To 
be respectful, she says "I did not remind them that I wanted to take the JAMB exam again and try for the university, that while going to secondary school I had sold more bread in Aunty Ada's bakery than all the other bakeries in Enugu sold" (para. 13). She again criticizes Aunty Ada and uncle Ike for the arrangement of her marriage that her feelings were of no importance and she had no right to interfere in her own marriage. As an immigrant, Chinaza needs to stick to familiar experiences such as culinary traditions and to use the Igbo language to ease the culture shock she is going through. Unsurprisingly, Ofodile's presence and behavior echo his cultural alienation and he does not support Chinaza in the process of culture shock. Chinaza feels the ambivalence when she finds out that Nia, their black American neighbor who lived three years in Tanzania "had chosen an African name, while my husband made me change mine to an English one" (Adichie 2009, para. 47). Chinaza's lack of power is evident. She has been treated as an object in her family where she has no right to express her feelings about the arranged marriage. Even Ofodile changes Chinaza's name for the Green Card application.

In the immigrant's life, the clash of assumption versus reality gives birth to ambivalence. Chinaza's life is riddled with struggles. She is stuck between her past in a patriarchal society and the present where she is again colonized at home. She could not go back to Nigeria because her family would be disappointed. On top of that, there could be no future with Ofodile since he is the colonizer at home. As a woman, Chinaza is doubly colonized. She has lived all her life according to the wishes of others, especially her family. As a woman, she has always been forced to ignore her wishes and feelings. As a woman in exile, she has to stay in a destructive relationship suppressing her emotions so that her family and 'new husband' would not be disappointed. As a human being, this is a sad story. After immigration, although her location changed, her circumstances did not. No feelings, no freedom, no future. Another point to note is that Ofodile is a self-colonizer character because forgetting one's own culture and mimicking the new one at all costs is a self-colonizing behavior. That is why their neighbor Nia nudges Chinaza to lead her own life and to be independent, "'You know, my sister's a manager at Macy's,' she said. 'They're hiring entry-level salespeople in the women's department, so if you're interested, I can put in a word for you and you're pretty much hired. She owes me one."' (Adichie 2009, para. 49). This conversation offers a ray of hope for Chinaza, "Something leaped inside me at the thought, the sudden and new thought, of earning what would be mine. Mine" (para. 49). In quest of freedom and prosperity, Chinaza realizes that being independent is better than being in a destructive relationship where the colonizer only believes in the mirror in front of himself. This crossroads of past and present gives birth to 'ambivalence'.

\section{CONCLUSION}

With the help of Bhabha's theories of mimicry and ambivalence, this article scrutinized the immigration experience in The Arrangers of Marriage (2009). Answering the first question of the research, the results indicate that Ofodile's self-alienation pushes him away from Chinaza. They grew apart from each other due to the fact that Ofodile constantly denies his Nigerian roots and desperately struggles to fit in the new society. This 'state of mimicry' intensifies gender inequality and discrimination against Chinaza. As the protagonist of the story, Chinaza's voice has been silenced for God-knows-how-long in a patriarchal culture. And unfortunately, this silence is considered absolutely normal by her family. Needless to say, Ofodile's offensive behavior with Chinaza is the result of this state of mimicry.

Answering the second question of the research, the results indicate that the place of immigrant's identity _in this context Chinaza_is placeless. That is, it is fluid and not fixed. Mentioning two points would be clarifying: First, the impact of the immigrant's past on the immigrant's today, and the impact of the immigrant's current situation on her future is an undeniable fact. Secondly, the immigrant always compares her different experiences: What has happened to her in the past, and what she experiences now. And the fluidity and place-less-ness of the immigrant's identity originates from this perpetual comparison. As the result of this comparison (past versus present), ambivalence is born that is crystal clear in Chinaza's behavior throughout the story. The immigrant can neither forget his past nor deny the present situation. The immigrant's past and present live together but never become one, like two oceans side by side. Although they go to the point of unification, they never become one and their difference remains eternal. Therefore, the identity of an immigrant is repeatedly in the process of formation. And comparing the past with the present situation is an integral part of this process. 


\section{REFERENCES}

Achebe, C. (1976). The Novelist As Teacher. In Morning Yet on Creation Day: Essays (pp. 55-60). New York: Anchor Press.

Adichie, C. N. (2009). The Arrangers Of Marriage. In The Thing Around Your Neck. HarperCollins Publishers. EPub.

Ashcroft, B., Griffiths, G., \& Tiffin, H. (2013). Postcolonial Studies: The Key Concepts (3rd ed.). London: Routledge.

Bhabha, H. (1994). The Location of Culture. London: Routledge.

Childs, P., \& Williams, P. (1997). An Introduction To Post-Colonial Theory. London: Routledge.

Eisenberg, E. (2013). "Real Africa"/“Which Africa?": The Critique of Mimetic Realism in Chimamanda Ngozi Adichie's Short Fiction. In E. Emenyonu (Ed.), Writing Africa in the Short Story (pp. 824). Boydell \& Brewer.

Gandhi, L. (2019). Postcolonial Theory: A critical introduction (2nd ed.). New York: Columbia University Press.

Huddart, D. (2006). Homi K. Bhabha. London: Routledge.

Kurtz, J. R. (2012). The intertextual imagination in Purple Hibiscus. Ariel: A Review of International English Literature, 42(2), 23-42.

Lubecka, A. (2012). Immigrants and their stories. In P. Leese, C. McLaughlin, W. Witalisz, \& E. Chrzanowska-Kluczewska (Eds.), Migration, narration, identity: Cross-cultural perspectives (text - meaning - context: Cracow studies in English language, literature and culture) (Vol. 6, pp. 133-144). Peter Lang GmbH, Internationaler Verlag der Wissenschaften.

McLeod, J. (2010). Beginning postcolonialism (2nd ed.). Manchester: Manchester University Press.

Miller, D. (2016). Strangers in Our Midst: The Political Philosophy of Immigration. Cambridge, Massachusetts: Harvard University Press.

Minh-Ha, T. T. (2010). Elsewhere, Within Here: Immigration, Refugeeism and the Boundary Event. New York: Routledge.

Sepehri, S. (2013). Book V: Sound of the Footsteps of Water (Sedayeh Payeh Ab). B. A. Shahid (trans.). In Sohrab Sepehri: A selection of poems from The Eight Books. Balboa Press. EPub. 
